\title{
PHYSIOLOGICAL AND REPARATIVE OSTEOGENESIS IN THE NORM AND UNDER CONDITIONS OF SELENIUM DEFICIENCY
}

Kovalchuk P. Ye., PhD in Traumatology, Assoc. Professor, Department of Traumatology and Orthopedics Tulyulyuk S. V., Assistant Department of Traumatology and Orthopedics Biryuk I. G., PhD in Anathomy, Professor, Department of Disaster Medicine and Military Medicine

Higher State Educational Establishment of Ukraine

"Bukovinian State Medical University», Ukraine

DOI: https://doi.org/10.31435/rsglobal_ws/31082019/6632

\section{ARTICLE INFO}

Received: 18 June 2019

Accepted: 20 August 2019

Published: 31 August 2019

\section{KEYWORDS}

osteogenesis, selenium, deficiency.

\begin{abstract}
The study presents the results of investigation of selenium deficiency condition on the bone tissue and healing post-traumatic bone defects under conditions of selenium deficiency.

The experimental part of the study was performed on 63 randomized brand albino male rats of 3-month age. Peculiarities of the reparative osteogenesis were studied on the model of a traumatic injury simulated one-type in the proximal meta-diaphysis of the femoral bone irrespective of the experimental conditions in the frontal plane in the form of perforated defect. The defect was made by means of a drill $1 \mathrm{~mm}$ in diameter.

The results of the study are indicative of a negative effect of selenium deficiency produced on physiological and reparative osteogenesis manifested by inhibition of the process and associated with disorders in the formation of osseous regeneration, deterioration of the structural-functional state of the osseous tissue, development of degenerative-necrotic changes in the osseous tissue and epiphyseal cartilage.
\end{abstract}

Citation: Kovalchuk P. Ye., Tulyulyuk S. V., Biryuk I. G. (2019) Physiological and Reparative Osteogenesis in the Norm and Under Conditions of Selenium Deficiency. World Science. 8(48), Vol.2. doi: 10.31435/rsglobal_ws/31082019/6632

Copyright: (C) 2019 Kovalchuk P. Ye., Tulyulyuk S. V., Biryuk I. G. This is an open-access article distributed under the terms of the Creative Commons Attribution License (CC BY). The use, distribution or reproduction in other forums is permitted, provided the original author(s) or licensor are credited and that the original publication in this journal is cited, in accordance with accepted academic practice. No use, distribution or reproduction is permitted which does not comply with these terms.

Among numerous minerals selenium occupies a special place as the most controversial trace element. $90 \%$ of selenium is found to be taken by a man with food, and only $10 \%$ — with water [4].

Deiodinases are selenium containing enzymes and their activity depends on its amount in food. For example, deficiency of selenium intake in rats during 5-6 weeks results in decreased production of $\mathrm{T} 3$ in the brain, liver and kidneys. Accordingly, T3 and T4 content increases or decreases in animals with selenium deficiency.

Today numerous researches evidence the effect of thyroid hormones on the development and metabolism of the skeletal tissues. Thyroid hormones in physiological concentrations are found to stimulate proliferation and activity of osteoblasts, that is, biosynthesis of the matrix macromolecules and its formation outside of the cells, promote proliferation and maturation of the epiphyseal cartilage chondrocytes facilitating the growth of bones at length [5]. A part of the mechanism of action of the thyroid hormones is availability of nuclear receptors in the osteoblast-like cells and osteoblasts, stromal cells of the bone marrow, osteoclasts and epiphyseal cartilage chondrocytes [1,2,3]. Deficiency of the thyroid hormones can cause development of osteopenia and osteoporosis.

The attempts to eliminate iodine deficiency diseases with administration of iodine containing drugs only, without preliminary supplement of selenium, increase a relative amount of goiter transformations (diffuse enlargement of the thyroid gland, nodular and mixed goiter, autoimmune 
thyroidism) from $18 \%$ to $83 \%$ [7, 9]. This effect is explained by a stimulating action of iodine containing agents on the function of the thyroid gland. It leads to activation of oxidation-reduction processes in the tissues. In case antioxidant protection of cells associated with selenium deficiency is disturbed, activation of redox processes in the glandular epithelium does not disappear.

Nowadays a number of unsolved issues remain and require their solution including effect of selenium deficiency conditions on the bone, healing of osseous defects and morphological peculiarities of the process under conditions of selenium deficiency.

Objective: to study in the experiment peculiarities of physiological and reparative osteogenesis in case of post-traumatic defects of the femoral meta-diaphysis under conditions of selenium deficiency.

Materials and methods: The experimental part of the study was performed on 63 randomized brand albino male rats of 3-month age. Peculiarities of the reparative osteogenesis were studied on the model of a traumatic injury simulated one-type in the proximal meta-diaphysis of the femoral bone irrespective of the experimental conditions in the frontal plane in the form of perforated defect. The defect was made by means of a drill $1 \mathrm{~mm}$ in diameter.

The animals were kept under conditions according to the requirements concerning their keeping and diet.

The experiment was conducted on the control and main group of animals.

The control group included 21 animals. The course of reparative osteogenesis was studied on them without use of pharmacological or physical effect on osteogenesis itself.

The main group included 42 rats divided into two subgroups 21 animals each.

Selenium deficiency in the main group of animals was simulated by means of diet with a low content of selenium (under $6 \mathrm{mcg} / 100 \mathrm{~g}$ ). 72 days later a perforated effect was made in the portion of the femoral proximal meta-diaphysis for all the animals. The first subgroup of animals was still kept under selenium deficiency conditions, and the animals from the second subgroup received diet with higher content of selenium (up to $55 \mathrm{mcg} / 100 \mathrm{~g}$ ) in combination with the pharmacological agent "Selenium-Active" in the dose of $55 \mathrm{mcg} / \mathrm{kg} /$ day.

The course of reparative osteogenesis under effect of the above induced conditions was investigated histomorphologically in the periods of 7,15 and 30 days after the defect was received.

Surgery was performed on the femur under conditions of an operating room in the vivarium of Higher State Educational Establishment of Ukraine "Bukovinian State Medical University" keeping to the rules of aseptic and antiseptic under Aminazine-Ketamine narcosis.

With the purpose to evidence selenium deficiency condition or its lack, the concentration of selenium in the urine was examined in the blood plasma. Blood was taken in the volume of $2 \mathrm{ml}$ by means of posterior vena cava puncture with further centrifugation. Before centrifugation officinal heparin solution in the dose of $250 \mathrm{UN} / \mathrm{ml}$ was added to the blood. Centrifugation was conducted with the use of the laboratory centrifuge SM6.03 at the speed of rotation of 1500 rotations per minute. Blood plasma was isolated from the used sample as a result of centrifugation. $1 \mathrm{ml}$ was taken from the obtained fractions for examination. The specimen was frozen at the temperature of $-33^{\circ} \mathrm{C}$.

The specimens were examined using selective atomic-absorptive analyzer МГА-915.

During the experiment the animals were kept under proper climatic conditions, keeping to 12-hour regimen of light and standard diet according to the requirements and international principles of the European Convention for the protection of vertebrate animals used for experimental and other scientific purpose: Council of Europe dated 18.03.1986. - Strasburg. - 1986. - 52 p.), the Law of Ukraine № 3447IV dated 21.02.2006 "On protection against cruelty to animals" and bioethics standards.

The material was statistically processed by means of the software Statisticav. 5.5. ShapiroWilk normality test was used to check the distribution. The hypothesis concerning statistical similarity of the two samples was checked by means of Student criterion, correlation analysis - by means of Spearman criterion.

Results. 7 days after the defect was got an active cellular proliferation was observed in the animals from the control group on the side of the periosteum and endosteum with the formation of the membrane reticulated osseous tissue against the ground of mildly manifested signs of hyperemia and swelling. The defect was filled with the newly formed osseous tissue in $31,86 \pm 1,06 \%$ (Fig. 1 a). In the animals from the first and second subgroups a network of the osseous membranes with irregular thickness was found. Intra-trabecular cells between them were filled mainly with fibroreticular bone marrow with a spread lumen of capillaries filled with blood and pronounced plasmostasis and swelling

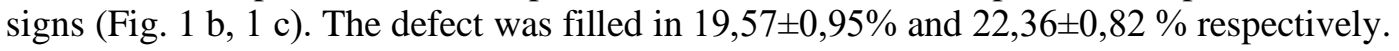



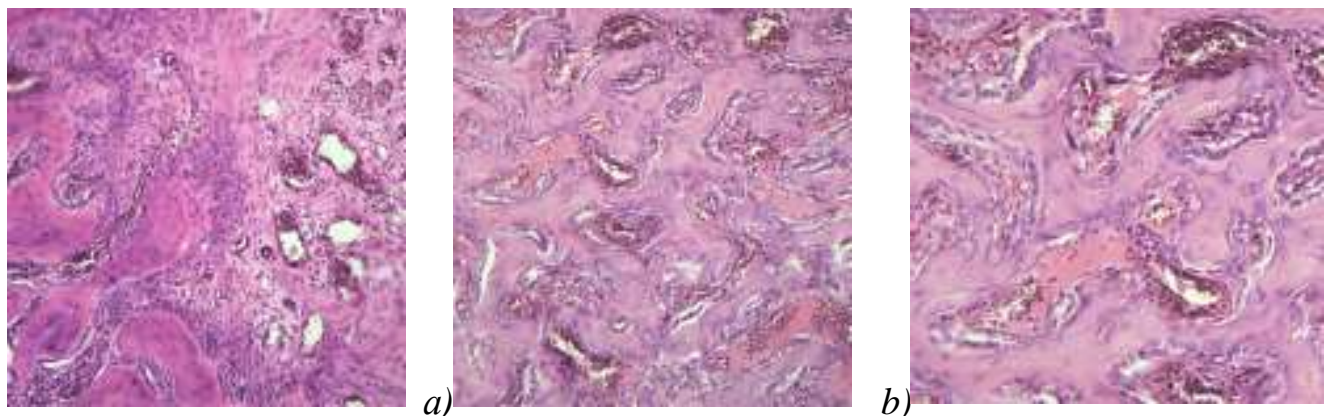

c)

Fig. 1. Formation of osseous lamellae of the membrane reticulated tissue. 7 days after injury (acontrol group, $b-$ I subgroup, $c-$ II subgroup).

15 days after the perforating defect was made in the animals from the control group microscopic examination was conducted and it determined slow formation of the periosteal osseous regeneration, which was mainly limited by the portion of diaphysis defect of the femoral bone. Endosteal reparative process was characterized by the formation of the membrane reticulated osseous tissue, and its rebuilding by filling the defect with the newly formed osseous tissue was $48,71 \pm 2,03 \%$ (Fig. 2.a). In animals from the first subgroup intra-trabecular cells are mainly filled with fibroreticular bone marrow with a spread lumen of capillaries filled with blood and pronounced plasmostasis and swelling signs. The compact osseous tissue in the margins of the defect of the femoral bone contained spread areas of necrosis. In their periphery the layer of the osseous tissue was formed in the shape of a closing plate (Fig. 2b). The defect was filled in $23,57 \pm 0,95 \%$. The second subgroup - gradual restoration of reparative activity of the osseous tissue formation accompanied by an increased activity of proliferation and osteoblast cellular elements, the defect was filled in $29,00 \pm 0,82 \%$ (Fig. 2.c).
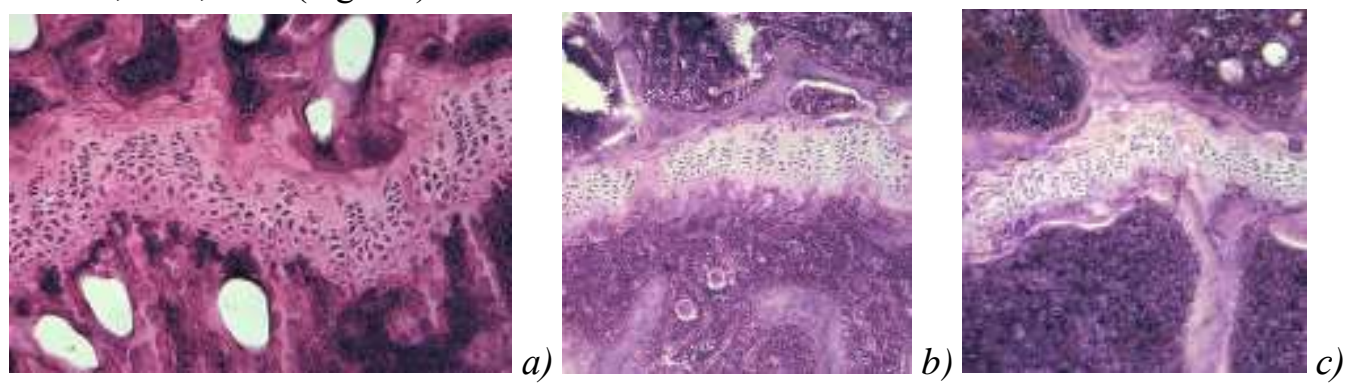

Fig. 2. Proximal epiphyseal cartilage. 15 days after injury (a-control group, $b$ - I subgroup, c - II subgroup).

30 days after receiving the defect in the animals from the control group proliferative activity of the epiphyseal cartilage cells and the process of endochondial ossification available are indicative of a rather high activity an physiological regeneration (formation) of the osseous tissue in the process of the longitudinal growth of the bone. The defect was filled with the newly formed osseous tissue in $95,42 \pm 2,03 \%$ (Fig. 3a). In animals from I subgroup certain peculiarities in the formation of osseous regeneration were observed, which were induced by selenium deficiency intake into the body. The changes found first of all touched upon proliferation and differentiation of cells into the osteoblasts, which are responsible for the formation of the osseous tissue. The defect was filled in $38,14 \pm 1,50 \%$ (Fig. 3b). II subgroup - reparative processes were progressing and resulted in the formation of the osseous tissue and its apposition on the surface of the bone lamellae. The intra-trabecular cells were filled with proliferating osteogenic cells. Few areas of osteoclasts were found. They resorbed dystrophic and necrotic changed osseous tissue. The defect was filled in $51,28 \pm 1,50 \%$ (Fig. 3c).
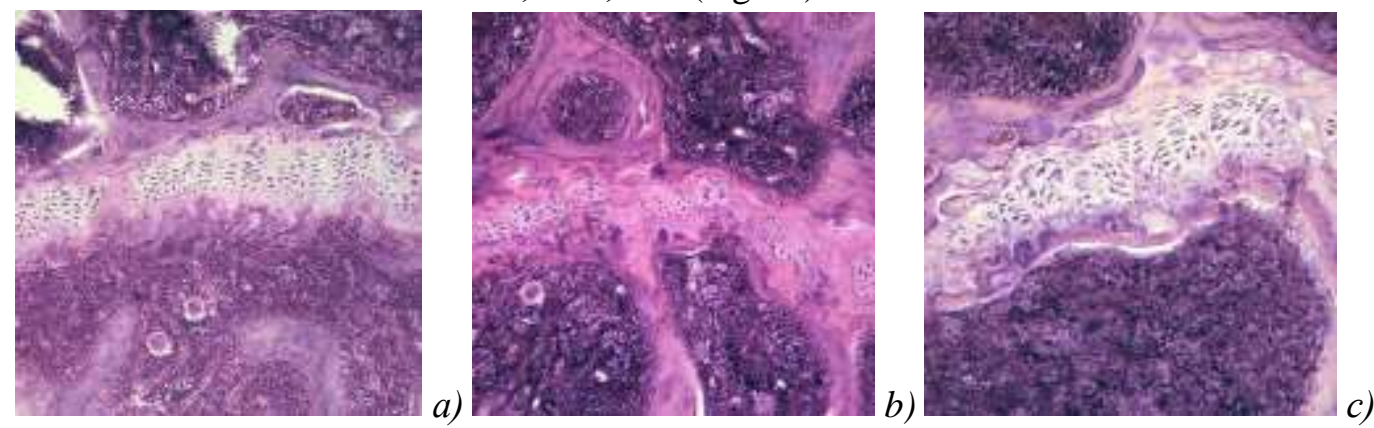

Fig. 3. Proximal epiphyseal cartilage. 30 days after injury (a-control group, b - I subgroup, c-II subgroup). 
Therefore, the data of the study are indicative of a negative effect of selenium deficiency produced on reparative and physiological osteogenesis manifested by inhibition of the processes and associated with disorders in the formation of osseous regeneration, deterioration of the structuralfunctional state of the osseous tissue, development of degenerative-necrotic changes in the osseous tissue and epiphyseal cartilage (Fig. 4).

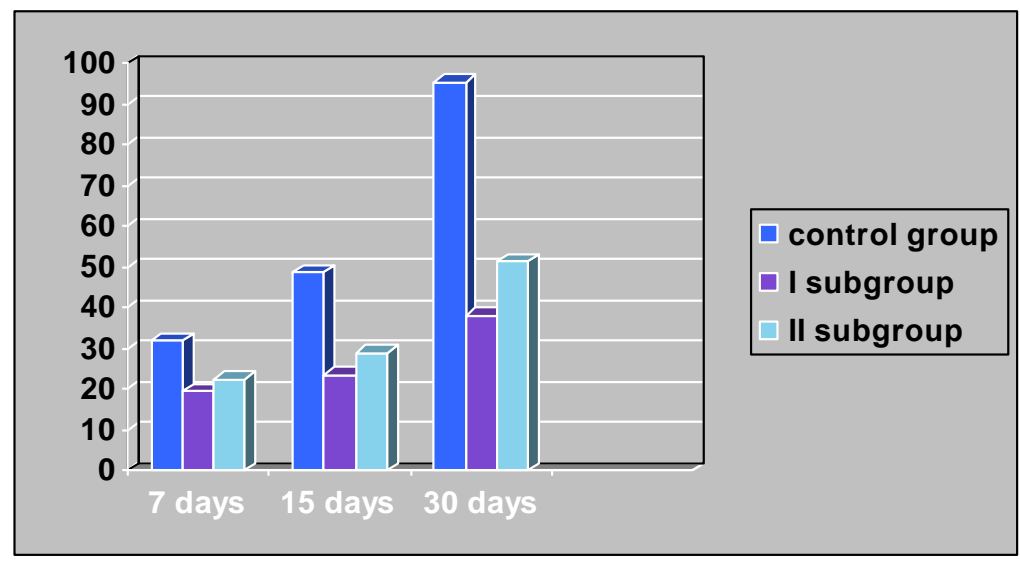

Fig. 4. Diagram of filling defect with newly formed osseous tissue.

\section{Conclusions.}

1. In animals from the experimental group with simulated selenium deficiency the osseous regeneration was slow, and its quality deteriorated due to secondary rebuilding associated with failure of regeneration to loading.

2. The first subgroup of experimental animals with simulated selenium deficiency was characterized by inhibition of stages of regeneration remodeling, which is reflected in the reduction of the relative area of the lamellar osseous tissue in comparison with that of the control.

3. A comprehensive treatment of rats with simulated selenium deficiency by means of "SeleniumActive" during the post-operative period results in reparative osteogenesis peculiar for the control animals.

\section{REFERENCES}

1. Бруско А. Т. Теореттичні та біологічні аспекти загоєння переломів кісток / А.Т. Бруско // Хірургічне лікування, медична реабілітація, фізіотерапія переломах при переломах кісток та захворюваннях суглобів: міжнар. наук.-практ. конф. 3 міжнар. уч., 10-11 квітня, 2008 р.: тези доп. - КиївМаньківка, 2008. - С. 14-17.

2. Григоровский В. В. Метаболическая реакция организма и репаративная регенерация кости при инициированном повреждении / В.В. Григоровский, С.М. Магомедов // Ортопед. травматол. - 2000. - № 2. - С. 101-102.

3. Зміни гормонального стану при ускладненому перебігу репаративного остеосинтезу після множинних та поєднаних переломів довгих кісток / О.О. Коструб, В.О. Литовченко, М.І. Березка [та ін.] // Проблеми остеології. - 2000. - Т. 3, № 4. - С. 35-36.

4. Моиссеенко Т.И. Рассеянные элементы в поверхностных водах суши / Т.И. Моиссеенко, Л.П. Кудрявцева, Н.А. Гашкина. - М.: Наука, 2006. - 261 с.

5. Danish investigation on iodine intake and thyroid disease Dan Thyr: status and perspectives / P. Laurberg, T. Jorgensen, H. Perrild, L. Ovsen [et al.] // European Journal of Endrinology. - 2006.- Vol. 155. - P. $219-228$.

6. Holmgren A. Selenoproteins of the thioredoxin system // Selenium. Its Molecular Biology and Role in Human Health / Ed. by D. L. Hatfield. — Boston, 2001. — P. 189-205.

7. Ren F. L. Efect of selenium and iodine deficiency on bone, cartilage growth plate and chondrocyte differentiation in two generations of rats / F.L. Ren R.X. Guo //Osteoarthritis Cartilage. - 2007. - Vol. 15.P. 1171-1177.

8. Visser T. J. The elemental impotance of ufficient iodine intake / T.J. Visser // Endocrinology. - 2006. Vol. 147, № 5. - P. 4039-4045.

9. Zagrodzki P., Nicol F., Arthur, J.R. Slowiaczek M. Selenoproteins in human thyroid tissues // Biofactors. - 2001. - Vol. 14. - P. 223-227. 